\title{
Andy Warhol: Documentaries and Biographical Films
}

Elizabeth Joan Kelly

J. Edgar \& Louise S. Monroe Library

Loyola University New Orleans

\section{Structured Abstract:}

Purpose: This paper aims to compile an annotated list of films about or pertaining to the artist Andy Warhol.

Design/methodology/approach: Films were located using library catalogs, databases, and online searches. Selections were evaluated through inspection and both academic and popular film reviews. Inclusion was predicated not only on subject matter and merit but also on availability either on home media or online.

Findings: Warhol's many artistic creations can be introduced and evaluated using a combination of visual and auditory representation. Movies and television depicting Warhol through dramatization, primary source film, biographical documentary, and his art in the context of other artists and movements are readily available through a variety of media.

Originality/value: The selected titles provide a comprehensive introduction to the scholarly analysis of Warhol's art and work through a format that allows the most extensive representation of Warhol's artistic output.

\section{Keywords:}

Resources, Collection management, Bibliographies, Film, Audiovisual media, Popular culture

\section{Article Classification:}

Literature Review

This is a preprint [pre-peer reviewed] version of a manuscript originally published in Collection Building 33, no. 3 (2014): 81-85. Permission to post the preprint here has been granted by Emerald Group Publishing Limited. 


\section{Andy Warhol: Documentaries and Biographical Films}

\section{Introduction}

This paper compiles an annotated list of films about or pertaining to Andy Warhol. As an artist, filmmaker, editor, writer, and record producer, Warhol worked in so many different media formats that beginning to analyze his output can be overwhelming. In addition, Warhol forged a public persona that has permeated our culture as much as his art has. Interpretation of Warhol's works often focuses as much on his eccentricity as it does on his actual art. The most cohesive way to begin learning about Warhol as an artist and as a person is through film, as the majority of his achievements can be represented through a combination of visual and auditory media.

As there are hundreds of films which feature archival footage or fictional representations of Warhol, this list is selective rather than comprehensive. Not included in this list are the films Warhol directed and produced, as descriptions and critical discussions of these are readily available elsewhere; nor are videos of museum exhibitions, which serve to replicate and analyze the experience of seeing Warhol's work but not of Warhol himself. Films are organized into four broad categories-dramatizations, primary source films, biographical documentaries, and Warhol in context. The films were selected for their content and availability. Most are still in print and are available for purchase or rental; the rest are out of print but may still be found either used or streaming online. Where films are unavailable for purchase, "Online only" is noted. This list may also be used for collection development purposes.

\section{Dramatizations}

Dramatizations of Warhol allow for analysis of how popular media has viewed him over time. Paul Morrissey, director of many of the movies Warhol produced, said of the film representations of Warhol, "You come away from Basquiat thinking Andy was comical and amusing, not a pretentious, phony piece of shit, which is how others show him." Writer Bob Colacello, editor of Warhol's Interview magazine, said "[Crispin] Glover [in The Doors] walked the most like [the real] Andy, [Jared] Harris talked the most like Andy, and Bowie looked the most like Andy" (Jewel, 1996). A newer representation of Warhol in the 2006 film Factory Girl lends another case for comparison. [The Doors is not included in this list as the Warhol character only appears briefly].

\section{Basquiat (1996)}

Directed by Julian Schnabel. 108 minutes. DVD, Echo Bridge Home Entertainment, 2011.

Documentary films tend to leave out Warhol's last decade. Warhol's friendship, mentorship, and collaboration with younger artist Jean-Michel Basquiat is an important plot point in this biopic directed by artist Julian Schnabel, himself a contemporary of Basquiat and Warhol. The Warhol Museum lent Warhol's actual wigs for David Bowie to wear in the film (Jewel, 1996). Includes some clips from Scenes from the Life of Andy Warhol by Jonas Mekas. 
Selected Cast: Jeffrey Wright (Jean-Michel Basquiat), Michael Wincott (Rene Ricard), Benicio Del Toro (Benny Dalmau), Claire Forlani (Gina Cardinale), David Bowie (Andy Warhol)

Factory Girl (2006)

Directed by George Hickenlooper. 90 minutes. DVD, The Weinstein Company, 2007.

This biopic about early Superstar and doomed socialite Edie Sedgwick explores her relationship with Warhol through flashbacks and reenactments of famous moments in both Sedwick and Warhol's lives.

Selected Cast: Sienna Miller (Edie Sedgwick), Guy Pearce (Andy Warhol), Hayden Christensen (Billy Quinn), Jimmy Fallon (Chuck Wein), Mena Suvari (Richie Berlin)

\section{Shot Andy Warhol (1996)}

Directed by Mary Harron. 106 minutes. DVD, MGM Home Entertainment, 2001.

Harron's I Shot Andy Warhol is a biopic about Warhol's would-be assassin and feminist writer Valerie Solanas. The movie was co-written with Jeremiah Newton, a close friend of Darling's and a real-life observer to the dynamics of Warhol's Factory in the late 60s.

Selected Cast: Lil Taylor (Valerie Solanas), Jared Harris (Andy Warhol), Martha Plimpton (Stevie), Lothaire Bluteau (Maurice Girodias)

\section{Primary Source Films}

These films were made during Warhol's lifetime and, unlike the biographical documentaries, do not offer critical commentary or context. They are instead visual representations of Warhol as he was.

\section{Andy Warhol and Roy Lichtenstein (1966)}

Directed by Lane Slate. 27 minutes. Online only.

This short film is perhaps the most duplicated in the many documentary films about Warhol. Dressed in black and seated in front of an Elvis painting, Warhol tells the interviewer, "You should just tell me the words and I'll repeat them. I'm so empty today, I can't think of anything." The interview includes Warhol introducing his newest foray, the Velvet Underground. The first half of the film is an interview with artist Roy Lichtenstein.

\section{Andy Warhol (Re-Reproduction) (1974)}

Directed by Toshio Matsumoto, 23 minutes. Online only.

This experimental film shows a slowed down kaleidoscope video of Warhol from the 70s. Sound is intentionally obscured.

Visions of Warhol (1963-1990) 
Directed by Willard Maas, Jonas Mekas, and Marie Menken. 69 minutes. DVD, Electronic Arts Intermix, 2000.

Visions is a compilation of four films made by avant-garde filmmakers and friends of Warhol. The compilation may be purchased for educational use. The individual films may also be found streaming online from various websites.

Comprised of:

- Award Presentation to Andy Warhol (1964, directed by Jonas Mekas. 12 minutes).

As Jonas Mekas described, "In 1964 Film Culture magazine chose Andy Warhol for its annual Independent Film award. The plan was to show some of Andy's films and have Andy come on stage and hand him the award. Andy said, no, he didn't want a public presentation. So I decided to hand him the award at the Factory, film the occasion, and show the film at the Award Presentation show at the New Yorker Theater. .. I was on my way to the Factory with three rolls of film when I remembered that I had nothing to present to Andy. So on the corner I bought a basket of mixed fruit. It was presented to Andy by Ivy Nicholson's little son" (Electronic Arts Intermix).

- Andy Warhol's Silver Flotations (1966, directed by Willard Maas. 4 minutes).

"Floating Clouds" exhibited at the Leo Castelli gallery in 1966. Maas' short film documents the experience of the exhibit.

- Andy Warhol (1965, directed by Marie Menken. 18 minutes).

This silent film shows Warhol at work with Gerard Malanga on a number of now-famous works including Brillo Boxes, paintings of Jackie Kennedy, and the Flowers paintings.

- Scenes from the Life of Andy Warhol (1990, directed by Jonas Mekas. 35 minutes).

Mekas's "film diaries" of Warhol from 1965-1982. These short snippets are extraordinary because they feature Warhol largely in social settings, including playing with houseguest Lee Radziwell's children at Warhol's house in Montauk; eating dumplings with John Lennon and Yoko Ono; and buying produce at the Union Square Farmer's Market.

\section{Biographical Documentaries}

Documentary films in this list are further broken down into those explicitly about Warhol and those about his circle of friends and associates.

\section{About Warhol}

These films present Warhol's life and art through archival footage and interviews with family, friends, associates, critics, scholars, and more. 


\section{Absolut Warhola (2001)}

Directed by Stanislaw Mucha. 80 minutes. DVD, TLA Releasing, 2004.

Director Mucha visits the Slovakian town of Miková, Warhol's parents' birthplace, to interview distant relatives who never met Warhol but who still show pride in his work and accomplishments. The film also visits the Andy Warhol Museum of Modern Art in Medzilaborce, Slovakia.

\section{Andy Warhol: A Documentary Film (2006)}

Directed by Ric Burns. 240 minutes. DVD, PBS Paramount, 2006.

Narrated by Laurie Anderson, the thesis of this film is that Picasso was the greatest artist of the first half of the $20^{\text {th }}$ century and Warhol the greatest of the second. Much of the footage is never-been-seen, and interviewees include a number of scholars, such as George Plimpton, writer Wayne Koestenbaum, art critic Dave Hickey, and Warhol biographer John Richardson; art dealers and gallery owners Irving Blum and Donna De Salvo; and Factory employees and friends Billy Name and Vincent Fremont. The film details Warhol's childhood but largely skips the 1970s and 1980s.

\section{Andy Warhol - The Complete Picture (2002)}

Directed by Chris Rodley. 105 minutes. DVD, Bfs Entertainment, 2003.

Andy Warhol - The Complete Picture focuses on the legacy of Warhol by discussing the "stuff" Warhol left behind-his "time capsules" and audio tapes at the Warhol Museum; his home in Montauk; the Andy Warhol Museum of Modern Art in Slovakia, supported by his brother John; and the large auction of Warhol's personal collection that happened shortly after his death. The documentary also questions the myth of Warhol as perverted voyeur, discussing his life-long church attendance, volunteer work at soup kitchens, and close relationship with his mother. This film best represents the entirety of Warhol's career of the documentaries mentioned here.

Andy Warhol's "Factory People" : Inside the 60's Silver Factory (2008)

Directed by Catherine O'Sullivan Schorr. 156 minutes. DVD, Planet Group Entertainment, 2010.

As the title notes, this film focuses on Warhol in the 1960s and the eclectic crowd of artists, actors, drug addicts, and other personalities who frequented the Silver Factory from 1964 until the Factory moved locations in 1968 and Valerie Solanas attempted to assassinate Warhol. The interviews used for the documentary were all newly conducted for the purpose of this film and include biographer Victor Bokris; Jonas Mekas; Vincent Fremont; and the titular "Factory People" including UltraViolet, Taylor Mead, Mary Woronov, Bibbi Hansen, Geraldine Smith, Louis Walden, and Allen Midgette, Gerard Malanga, Billy Name, and Brigid Berlin.

\section{Portrait of an Artist: Andy Warhol (1987)}

Directed by Kim Evans. 79 minutes. VHS, Homevision, 2001. 
This was the first major film made about Warhol after his death in 1987 and introduces the artist to the beginning researcher. Interviews include art dealers, gallery owners and Warhol's inner circle. Film clips are from Warhol's films, interviews, and previously unseen footage from London shortly before his death. The documentary is more about Warhol's art than his life, with a special focus on his 1960s films.

Superstar: The life and times of Andy Warhol (1991)

Directed by Chuck Workman. 87 minutes. DVD, Shout Factory, 2003.

Superstar works as a collage of Warhol's many sides: his extreme celebrity and the resulting friendships his celebrity earned him (Dennis Hopper, artist David Hockney) are contrasted with the lives of his brothers, Paul and John Warhola, and cousins back in Pennsylvania. Clips from news and television firmly place Warhol within the mass media of his time. The film, like most, focuses largely on the 1960s and Warhol's film work, but also covers his childhood, years in college, and later works including the posthumous establishment of the Warhol Foundation from the sale of his personal collection at Sotheby's.

Warhol (1973)

Directed by Bill Verity . 47 minutes. DVD (UK only), Network, included on Bailey On (2006).

This TV movie attempts to capture Warhol using his own film techniques as interviewed by celebrated British photographer David Bailey. An actor reenacts Warhol quotes, and when Warhol is on screen he moves his mouth while someone else answers Bailey's questions. The film was largely controversial at its time and includes scenes of a topless Brigid Berlin.

\section{About Warhol's Circle}

Warhol was eventually as recognized for his fame as he was for his art, and his public persona was in no small part characterized by the company he kept. Some of Warhol's inner circle were artists themselves; others were actors, writers, and musicians. Much can be gleaned from the lives of those Warhol created with, and films about these personalities tend to spend a significant amount of time on the subject's relationship with Warhol.

\section{Beautiful Darling (2010)}

Directed by James Rasin. 87 minutes. DVD, Corinth Films, 2010.

This film documents Warhol Superstar Candy Darling's birth as James Slattery followed by her film and theater career and is produced by long-time friend Jeremiah Newton. The narration by Chloe Sevigny includes excerpts from Darling's diary.

Jack Smith and the Destruction of Atlantis (2006)

Directed by Mary Jordan. 95 minutes. DVD, Arthouse Films, 2010. 
Smith was a contemporary of Warhol's in the avant-garde film world as well as an actor in several of Warhol's films. In this documentary, Warhol calls Smith "my best director" and "The only person I would ever copy." Smith criticized Warhol's success and fame as he himself shied away from commercial media by intentionally not finishing his remaining films and re-cutting them live for each showing. The documentary is comprised of rare archival footage, interviews, audio recordings, and clips from Smith's films, focusing both on his work as a director/actor and on his life.

Jean-Michel Basquiat: The Radiant Child (2010)

Directed by Tamra Davis. 88 minutes. DVD, Arthouse Films, 2010.

Basquiat was briefly the star of the New York art world. This film follows his birth, rise, and rapid decline through archival footage and interviews. His friendship and collaboration with Warhol in the 1980s is included and provides a rare glimpse into Warhol's later years.

\section{Lou Reed: Rock and Roll Heart (1998)}

Directed by Timothy Greenfield-Sanders. 73 minutes. DVD, Winstar, 1998.

Reed's career is so prolific that his early work with the Warhol-produced Velvet Underground could be simply a prelude to his later output, but nearly a third of this documentary covers the creation of the "Velvets" and their initial role as Factory house band. The film also discusses Reed and fellow Velvet John Cale's reunion following Warhol's death to record Songs for Drella.

\section{Nico Icon (1995)}

Directed by Susanne Ofteringer. 67 minutes. DVD, Fox Lorber, 1998.

Chanteuse Nico was involved with Warhol for a short period in the mid to late 1960s, acting in several Warhol films and performing with the Velvet Underground at his insistence, before breaking out on her own as a solo musician and actress and then descending into drug addiction. The film is comprised of interviews, film clips, archival footage, and musical performances.

\section{Pie in the Sky: The Brigid Berlin Story (2000)}

Directed by Shelly Dunn Fremont and Vincent Fremont. 75 minutes. DVD, Docurama, 2001.

Few of Warhol's early entourage made the transition from the Silver Factory and his art and film work to the subsequent Factories and Interview magazine, but the mutually creative relationship between Warhol and Brigid Berlin continued until his death. Both were obsessed with recording everything with tape recorders and Polaroids; Warhol's only play, Pork, was based on Berlin's phone conversations with her mother. And Berlin is an artist in her own right, a fact not often mentioned in other Warhol documentaries but explored here.

Superstar in a Housedress (2004) 
Directed by Craig Highberger. 95 minutes. DVD (sold with book of the same), Highberger Media Inc., 2005.

Jackie Curtis was one of Warhol's cross-dressing Superstars who also had a successful career as a playwright. Curtis' influence was felt as widely as actors Bette Midler, Lily Tomlin, and Harvey Fierstein. The film includes rare footage of Curtis's off-off-Broadway performances.

A Walk Into the Sea: Danny Williams and the Warhol Factory (2007)

Directed by Esther B. Robinson. 75 minutes. DVD, Arthouse Films, 2008.

Factory film editor, camera operator, and possible Warhol lover Danny Williams disappeared in 1966. This documentary, directed by his niece, attempts to find out what happened to him through archival footage and interviews with family and Factory regulars. Williams is absent from most Warhol biography, so this movie contains some rare footage (some shot by Williams). The Whitney Museum's Andy Warhol Film Project curator Callie Angell is featured as her discovery of Williams's films helped spawn director Robinson's interest.

\section{Warhol in Context}

These documentaries discuss Warhol's art within the greater context of art history.

\section{Painters Painting (1973)}

Directed by Emile de Antonio. 116 minutes. DVD, Arthouse Films, 2010.

This film documents post-WWII modernist painting in New York through extended interviews with artists Willem de Kooning, Helen Frankenthaler, Jasper Johns, Jules Olitski, Larry Poons, Robert Rauschenberg, Frank Stella, and Andy Warhol as well as dealers (Leo Castelli), collectors (Ethel and Robert Scull), curators (Henry Geldzahler), and more.

The Shock of the New, Episode 7: Culture as Nature (1982)

Directed by Robert Hughes. 60 minutes. DVD (as four DVD set containing all eight episodes), Ambrose Video Publishing, 2001.

The Shock of the New is an eight-part television series about the history of modern art from the Impressionists through the 1980s. "Episode 7: Culture as Nature" introduces art that was influenced by and incorporated popular culture, including Dada and Pop Art.

\section{Who Gets to Call It Art? (2006)}

Directed by Peter Rosen. 78 minutes. DVD, Palm Pictures / Umvd, 2006.

Metropolitan Museum of Art curator Henry Geldzahler was a champion of the contemporary art scene in 1960s New York. In addition to curating the highly controversial Met show "New York Painting and Sculpture: 1940-1970," Geldzahler engaged in unprecedented relationships with the artists he 
supported, appearing in films by Warhol, paintings by David Hockney and others, and a "happening" by Claes Oldenberg. Who Gets to Call It Art? is simultaneously a biography of Geldzahler and a history of post-WWII American art through Geldzahler's critical eye.

\section{Additional Resources}

Internet Movie Database (http://www.imdb.com/)

$I M D b$ is a free source for information about movies, television shows, and cast and crew. Cast information for the films discussed in this paper can be found here as can information pertaining to additional films about or featuring Warhol.

\section{The Warhol Museum}

The Warhol Museum in Pittsburgh has 350 of Warhol's films as well as all of his personal videotapes including "video diaries, experimental soap operas, music videos, commercial work-for-hire, and all completed episodes of the television series Fashion, Andy Warhol's T.V. and Andy Warhol's Fifteen Minutes" (The Warhol).

\section{The Whitney Museum and the Museum of Modern Art (MOMA)}

The Whitney and MOMA (both in New York City) have been collaborating on the Andy Warhol Film Project since 1984, cataloguing, researching, preserving, and re-releasing Warhol's films. The museums have hosted presentations of Warhol's films along with panel discussions and lectures. MOMA rents some of Warhol's films for a fee through the MOMA website (MOMA).

UbuWeb (http://www.ubuweb.com/)

This website makes avant-garde film available for noncommercial and educational use. Includes several of Warhol's films as well as films about Warhol.

\section{References}

Electronic Arts Intermix: Award Presentation to Andy Warhol. Available from http://www.eai.org/title.htm?id=14148. [26 March 2014].

Jewel, D. (1996), "The Art of being Andy", People Magazine, Vol. 46 Issue 9, p. 18.

"MOMA: Contacting the circulating film and video library," available at http://www.moma.org/learn/resources/circulatingfilm\#aboutcircfilm [1 April 2014]

"The Warhol: Film and video collection," available at http://www.warhol.org/collection/filmandvideo/ [1 April 2014] 